\title{
Kwestia narodowościowa na peryferiach Europy Środkowo-Wschodniej. Przypadek Polesia między dwiema wojnami
}

Zarys treści: Artykuł przedstawia projekty narodowe, które zaistniały na Polesiu w okresie międzywojennym i dążyły do unarodowienia miejscowej ludności. Skrótowo zostały omówione uwarunkowania od zakończenia I wojny światowej do podpisania traktatu ryskiego w marcu 1921 r., wpływające w sposób zasadniczy na dalsze postawy Poleszuków. Województwo poleskie w granicach odrodzonej Polski było terenem współzawodnictwa ruchów narodowych: białoruskiego, polskiego, rosyjskiego i ukraińskiego. Wyraźne załamanie tej rywalizacji na Polesiu miało miejsce na przełomie 1932/1933 r. Od tego czasu wojewoda poleski Wacław Kostek-Biernacki zdecydowanie zwalczał wszelkie niepolskie przedsięwzięcia w regionie.

Outline of content: The article presents national projects which were conceived in Polesia in the interwar period and aspired to nationalise the local population. The study is set in context by a brief description of circumstances between the end of World War One and the Treaty of Riga in March 1921, which had a profound influence on the attitudes of the people from Polesia. The Polesia Province within the borders of reborn Poland was an area of fierce competition between Belarusian, Polish, Russian, and Ukrainian national movements. A clear breakthrough within this competition took place at the turn of 1933. From that time on, the Polesia voivode Wacław Kostek-Biernacki fought against all non-Polish actions in the region.

Slowa kluczowe: II Rzeczpospolita, Polesie, projekt narodowy, Białorusini, Polacy, Rosjanie, Ukraińcy

Keywords: Second Polish republic, Polesia, national project, Belarusians, Poles, Russians, Ukrainians

Pierwsza wojna światowa, której wynikiem był rozpad trzech potęg imperialnych - Austro-Węgier, Niemiec i Rosji, doprowadziła również do zasadniczej zmiany stosunków narodowościowych w Europie Środkowej i Wschodniej. Na gruzach imperiów odradzały się wcześniej istniejące państwa, takie jak Polska, 
bądź wyłaniały się zupełnie nowe - Litwa, Łotwa i Estonia. Własne aspiracje państwowe, które jednak nie były skuteczne, zgłosili również Białorusini i Ukraińcy. Wielką nadinterpretacją jednak byłoby twierdzenie, że po I wojnie światowej idea narodu ostatecznie zwyciężyła w tej części Europy. W przypadku narodów niehistorycznych aspiracje niepodległościowe często były tylko pomysłem wąskiego kręgu narodowej elity, która $\mathrm{z}$ różnych przyczyn mogła mieć ograniczone wpływy wśród własnych pobratymców. Zjawiskiem charakterystycznym dla ziem dawnego Wielkiego Księstwa Litewskiego było współistnienie zarówno grup o określonej świadomości narodowej, jak i tych, co takiej świadomości nie posiadały i często utożsamiały się przez wyznanie lub przestrzeń lokalną ${ }^{1}$. Hermetyczne społeczności chłopskie nawet pod koniec okresu międzywojennego mogły nie mieć wyrobionej świadomości narodowej. Nie ulega jednak wątpliwości, że pozyskanie i unarodowienie tych grup ludności stawało się kluczem do efektywnego sprawowania władzy na podległym terenie.

Tekst poświęcony jest problemowi rozwoju kwestii narodowościowej na terenie peryferyjnym, czyli na międzywojennym Polesiu. Określenia „Polesie” $i$ „województwo poleskie” będą stosowane synonimicznie, mimo że pierwszy termin jest również pojęciem geograficznym w znacznej mierze szerszym od jednostki administracyjnej w granicach II Rzeczypospolitej w latach 1921-1939. Przede wszystkim zostaną zaprezentowane postulaty ruchów białoruskiego, polskiego, rosyjskiego i ukraińskiego zamierzających poszerzyć swoje wpływy na Polesie. Głównym celem powyższych roszczeń było unarodowienie prawosławnej wiejskiej ludności, która liczebnie absolutnie przeważała w tym regionie ${ }^{2}$. $\mathrm{Z}$ tego powodu zasadniczo zrezygnowano z przedstawienia wątku żydowskiego, ponieważ Żydzi nie mieli aspiracji narodowych poza obrębem własnej wspólnoty religijnej. Trzeba jednak jednocześnie pamiętać, że ludność żydowska stanowiła około $10 \%$ ogółu mieszkańców regionu oraz zajmowała wręcz wyjątkowe miejsce $\mathrm{w}$ strukturze społecznej z powodu gospodarczej dominacji w poleskich miastach i miasteczkach ${ }^{3}$.

Przed I wojną światową kwestia narodowościowa na Polesiu w zasadzie nie istniała. W Rosji carskiej autochtoniczna ludność Polesia była uważana za białoruski lub małoruski szczep narodu rosyjskiego. Ludność regionu pozostawała w stanie surowej masy etnograficznej, nie mając wyrobionej świadomości narodowej. Narodowa agitacja na tym terenie do Wielkiej Wojny miała w gruncie rzeczy

${ }^{1}$ S. Ciesielski, Kresy Wschodnie - dynamika przemian narodowościowych, w: Kresy Wschodnie II Rzeczypospolitej. Przekształcenia struktury narodowościowej 1931-1948, red. S. Ciesielski, Wrocław 2006, s. 7.

2 Według spisu ludności z 1921 r. w województwie poleskim mieszkało około 700 tys. wyznawców prawosławia, co stanowiło ponad 79\% całej populacji, zob. Pierwszy powszechny spis Rzeczypospolitej Polskiej z dnia 30 września 1921 roku. Mieszkania. Ludność. Stosunki zawodowe. Województwo Poleskie, Warszawa 1926.

3 W. Śleszyński, Województwo poleskie, Kraków 2014, s. 89. 
charakter marginalny ${ }^{4}$. Wśród jej nielicznych przejawów sprzed I wojny światowej na Polesiu warto odnotować kolportaż białoruskiej gazety „Nasza Niwa”"

W latach 1915-1920 Polesie było teatrem działań wojennych. W tym miejscu należy jedynie zasygnalizować zmiany, które wkrótce wpłynęly na postawy Poleszuków. Pod okupacją niemiecką zakładano szkoły ludowe w językach miejscowej ludności, wydając równocześnie zakaz używania języka rosyjskiego w dziedzinie oświaty. $W$ ten sposób na Polesiu powstawały szkoły ukraińskie, będące raczej narzędziem niemieckiej polityki derusyfikacji tego obszaru, aniżeli skutkiem pragnień miejscowej ludności. Według danych z sierpnia 1917 r. na Polesiu działało 21 ukraińskich szkół z 1250 uczniami ${ }^{6}$.

Ogromne znaczenie miała zarówno przymusowa, jak i dobrowolna ewakuacja miejscowej ludności na Wschód, przeprowadzona przez władze rosyjskie. Wcześniej przeciętny Poleszuk w trakcie swojego życia rzadko opuszczał nawet rodzinną wieś. Pod tym względem doświadczenie uchodźcze nabyte w okresie wojny domowej w Rosji poszerzało horyzonty myślowe oraz wnosiło element radykalizmu społecznego w postawę życiową poleskiego chłopa. Repatrianci wracający z Rosji do swoich domów na początku lat dwudziestych XX w. w sposób zasadniczy różnili się od Poleszuków sprzed I wojny światowej. Wracając do swych siedzib, zastawali w tym miejscu odrodzone państwo polskie, do którego raczej nie byli przekonani. Stąd dość chętnie zasilali szeregi partii komunistycznej oraz legalnych organizacji lewicowych o białoruskim bądź ukraińskim zabarwieniu narodowym ${ }^{7}$. Jak się również wydaje, polonizacyjne zapędy władz II Rzeczypospolitej budziły w nich opór. Według danych Alfonsa Krysińskiego, na Polesie do stycznia 1923 r. wróciło ponad 103 tys. repatriantów ${ }^{8}$.

Za ważną cezurę należy uważać zawarcie traktatu pokojowego między państwami centralnymi a Ukraińską Republiką Ludową (URL), który podpisano 9 lutego 1918 r. w Brześciu. Według układu Niemcy i ich sojusznicy nie tylko uznawali podmiotowość państwa ukraińskiego, ale i przekazywali URL tereny Polesia, Chełmszczyzny oraz części Podlasia. Do wspomnianych terenów ze względów historycznych i etnicznych zgłaszali roszczenia również Polacy. Delegacja Królestwa Polskiego nie została jednak dopuszczona do rozmów przez żadną ze stron negocjacji pokojowych. Wysłannicy białoruscy zostali natomiast zatrzymani

\footnotetext{
${ }^{4}$ L. Wasilewski, Sprawa Kresów i mniejszości narodowych w Polsce, Warszawa 1925, s. 20.

5 П. Терешкович, Этническая история Беларуси ХІХ - начала ХХ в. в контексте Центрально-Восточной Европь, Минск 2004, s. 180.

${ }^{6}$ I. Винниченко, Україниі Берестейщини, Підлящшя й Холмщини в перщій половині ХХ ст. Хроніка подій, Київ 1997, s. 37.

7 P. Cichoracki, Działalność wywrotowa w województwach pótnocno-wschodnich II Rzeczypospolitej Polskiej - jedno z następstw Wielkiej Wojny, w: Wojna i ludzie. Społeczne aspekty I wojny światowej w Europie Wschodniej, red. D. Michaluk, Ciechanowiec 2015, s. 349.

8 A. Krysiński, Liczba i rozmieszczenie Ukraińców w Polsce, „Sprawy narodowościowe” (1928), nr 6, s. 664 .
} 
przez bolszewików przed linią frontu i zmuszeni do podróży okrężną drogą od strony Ukrainy. Bolszewicy również nie wyrazili zgody na uczestnictwo białoruskiej reprezentacji w obradach pokojowych. Ostatecznie Białorusini uzyskali jedynie status obserwatora przy delegacji ukraińskiej ${ }^{9}$.

Skutkiem Wielkiej Wojny i dekompozycji Imperium Rosyjskiego było ożywienie kwestii narodowościowej na Polesiu i zmiana dotychczasowego układu sił w regionie. Po 1918 r. stało się ono nie tylko polem rywalizacji odrodzonego państwa polskiego i Rosji bolszewickiej, ale też przestrzenią zainteresowania ruchów narodowych białoruskiego i ukraińskiego. Skala działania tych ruchów była różna. Działacze białoruscy jedynie zadeklarowali roszczenia wobec Polesia. Ukraińcy po traktacie brzeskim bezskutecznie próbowali tworzyć struktury władzy na miejscu. Pierwsza grupa ukraińskich urzędników wyruszyła z Kijowa do Brześcia w kwietniu 1918 r. Polesie wciąż znajdowało się pod okupacyjną władzą niemieckiej administracji wojskowej, która w gruncie rzeczy nie przeszkadzała Ukraińcom prowadzić działalności kulturalno-oświatowej. Bezpośredni uczestnik opisywanych wydarzeń, Wasyl Dmytriuk, wspomina, że w tym okresie w Brześciu zostało założone ukraińskie towarzystwo „Proświta”. Oprócz tego trzykrotnie odbywały się kursy dla nauczycieli ukraińskich szkół ludowych ${ }^{10}$.

Po 11 listopada 1918 r. niemiecka armia okupacyjna, która na tym terenie stanowiła bufor pomiędzy siłami polskimi i bolszewickimi, zaczęła się wycofywać w szybkim tempie. Bezpośrednie starcie wojsk polskich i bolszewickich miało rozstrzygnąć polityczny status ziem byłego Wielkiego Księstwa Litewskiego. W lutym 1919 r. w Brześciu pojawiły się oddziały Wojska Polskiego. Polesie, ze względu na podmokły teren, nie było obszarem sprzyjającym prowadzeniu działań wojennych. Na odcinku poleskim Wojsko Polskie ścierało się z nielicznymi oddziałami bolszewickimi i już 5 marca dotarło do Pińska.

Jednocześnie niezwykle ważnym czynnikiem, mającym określić przyszłości ziem na wschód od Bugu, był polsko-polski spór o kształt odrodzonego państwa. Naczelnik Państwa Józef Piłsudski opowiadał się za ścisłym związkiem ziem dawnego Wielkiego Księstwa Litewskiego z Polską na zasadach federacyjnych. W tym celu został powołany Zarząd Cywilny Ziem Wschodnich (ZCZW), mający stworzyć warunki dla przyszłej federacji i umożliwić przeprowadzenie plebiscytu zapowiedzianego w odezwie Piłsudskiego Do mieszkańców byłego Wielkiego Księstwa Litewskiego z 22 kwietnia 1919 r. Okres funkcjonowania ZCZW uwidocznił, że pozyskanie ludności ziem dawnego Wielkiego Księstwa Litewskiego na rzecz federacji z Polską jest zadaniem niezwykłe trudnym ${ }^{11}$. Z kolei obóz narodowy na czele z Romanem Dmowskim propagował bezpośrednie wcielenie ziem wschodnich

9 D. Michaluk, Białoruska Republika Ludowa 1918-1920. U podstaw białoruskiej państwowości, Toruń 2010, s. 219.

10 В. Дмитріюк, Дорогами війни та миру, [b.m.w.] 2012, s. 59.

11 Zob. J. Gierowska-Kałłaur, Zarząd Cywilny Ziem Wschodnich (19 lutego 1919 - 9 września 1920), Warszawa 2003. 
i utworzenie polskiego państwa narodowego. Swoistym intermezzo stała się ofensywa Armii Czerwonej i krótkotrwałe zainstalowanie na Polesiu rządów bolszewickich latem 1920 r. Odpowiednia bolszewicka indoktrynacja oraz próba natychmiastowej zmiany stosunków społecznych mocno zradykalizowała miejscowe chłopstwo.

Spory wokół kształtu wschodniej granicy Polski trwały prawie dwa lata i zakończyły się porażką zwolenników koncepcji federacyjnej. Zawarcie traktatu pokojowego w Rydze 18 marca 1921 r. przesądziło o wcieleniu zachodniej części Polesia do państwa polskiego, natomiast jeszcze w lutym $1921 \mathrm{r}$. na tym terenie zostało utworzone województwo poleskie. W Polsce międzywojennej była to jednostka administracyjna $\mathrm{z}$ najmniejszym odsetkiem ludności polskiej ${ }^{12}$.

Dalszy rozwój kwestii narodowościowej na Polesiu odbywał się już w ramach II Rzeczypospolitej. Generalnie rzecz biorąc, w okresie międzywojennym region wciąż pozostawał na peryferiach oddziaływania ruchów narodowych. Największym paradoksem jednak było to, że na Polesiu zbiegały się interesy wielu z nich: białoruskiego, polskiego, rosyjskiego oraz ukraińskiego. W koncepcjach terytorialnych wszystkich tych ruchów Polesie stanowiło integralną część ich „idealnej Ojczyzny”, stąd region $\mathrm{w}$ dwudziestoleciu międzywojennym był swoistą przestrzenią narodowej rywalizacji. Należy jednak zastrzec, że skala narodowej agitacji w przypadku poszczególnych ruchów znacząco się różniła. Można również zaobserwować olbrzymią różnicę w jej natężeniu w pierwszej i drugiej dekadzie dwudziestolecia międzywojennego. Ze względu na powyższe wypadałoby zajrzeć do programów starych i nowych podmiotów narodowych na Polesiu.

\section{Polski projekt narodowy}

Oblicze etniczne Polesia kształtowała prawosławna masa chłopska bez wyraźnej świadomości narodowej. Z punktu widzenia Warszawy, posiadającej unifikacyjny aparat państwowy, powyższa okoliczność nie stanowiła wielkiego problemu dla unarodowienia nieuświadomionych Poleszuków w duchu polskim. Bez głębszej refleksji wierzono wówczas w atrakcyjność polskiej kultury dla miejscowej ludności, odwołując się do czasów Rzeczypospolitej Obojga Narodów. Nie chciano natomiast brać pod uwagę różnic etnicznych i wyznaniowych, które w epoce coraz bardziej rosnącego nacjonalizmu stawały się fundamentem dla konstruowania nowoczesnej świadomości narodowej.

W gruncie rzeczy panowało przekonanie, że proces odbudowy powojennych zniszczeń oraz inwestowanie w gospodarkę regionu doprowadzą do samorzutnej polonizacji Poleszuków, zaś bierna narodowościowa postawa miejscowej ludności tylko miała przyśpieszyć ten proces. Jak twierdził wojewoda Stanisław

12 Drugi powszechny spis Rzeczypospolitej Polskiej z dn. 9 XII 1931 r. Mieszkania i gospodarstwa domowe. Ludność. Stosunki zawodowe. Województwo Poleskie, Warszawa 1938. 
Downarowicz, „nie ma zbyt wielkich wysiłków i ofiar, na które bez zwłoki winna się zdobyć Polska dla przeprowadzenia na Polesiu szerokiego programu gospodarczego, który nie tylko się opłaci, ale zabezpieczy olbrzymie zdobycze narodowe i polityczne"13. Jego następca Kazimierz Młodzianowski był przekonany, że „do serca tego ludu trafia się przede wszystkim przez żołądek"14.

Warto podkreślić, że miejscowy polski albo potencjalnie polski element odgrywał w tych planach rolę marginalną. Polacy od dawna zamieszkiwali na Polesiu, stanowiąc w czasach nowożytnych absolutną większość wielkich posiadaczy ziemskich, choć wskutek antypolskiej polityki władz Imperium Rosyjskiego odsetek elementu polskiego wśród nich zmalał. Mimo tego pośród właścicieli gospodarstw powyżej 50 ha Polacy stanowili $65,2 \%$. W gospodarstwach o wielkości powyżej 100 ha odsetek posiadaczy narodowości polskiej był jeszcze większy ${ }^{15}$. Znamienne jest, że administracja wojewódzka nie tylko nie rozpatrywała ziemiaństwa jako sojusznika w sprawie polonizacji Polesia, lecz zaznaczała jego egoistyczną postawę oraz nierozumienie potrzeb polskiej racji stanu $\mathrm{w}$ regionie ${ }^{16}$.

Potomkowie dawnej szlachty zagrodowej byli kolejną, tym razem już tylko potencjalną polską społecznością na Polesiu. Liczbę szlachty, która przeważnie zamieszkiwała zwartymi skupiskami całe wsie głównie w powiatach pińskim, stolińskim oraz łuninieckim województwa poleskiego, szacowano na około 30 tys. osób ${ }^{17}$. Obecność szlachty zagrodowej we wschodnich województwach II Rzeczypospolitej szczególnie mocno eksponowano $\mathrm{w}$ drugiej połowie lat trzydziestych. W województwie poleskim pomysł roztoczenia szczególnej opieki nad szlachtą spotkał się z dezaprobatą lokalnej administracji, która widziała w nim źródło dodatkowych społecznych napięć na wsi. Wydaje się, że na Polesiu akcja narodowej i wyznaniowej rewindykacji szlachty - jak to ujął propagator tych poczynań Stanisław Dworakowski - zaistniała jedynie w sferze propagandy ${ }^{18}$.

W zarysowanej sytuacji wyjątkowej słabości miejscowego żywiołu polskiego pewne nadzieje pokładano w kolonizacji regionu. Perspektywy szerokiego

13 Program wojewody poleskiego Stanisława Downarowicza o zadaniach i pracach państwowych na Polesiu skierowany do Wydziału Narodowościowego Ministerstwa Spraw Wewnętrznych z 28 II 1923, w: Polesie w polityce rząów II Rzeczypospolitej, red. W. Śleszyński, Białystok-Kraków 2009, s. 36.

${ }^{14}$ Protokół $z$ wystąpienia wojewody poleskiego podczas pierwszego zebrania periodycznego przedstawicieli urzędów władz II instancji w Poleskim Urzędzie Wojewódzkim z 20 VII 1925, w: Protokoły i raporty zebrań wojewodów i starostów - województwo poleskie, red. W. Śleszyński, Kraków 2014, s. 30.

15 J. Tomaszewski, Z dziejów Polesia 1921-1939. Zarys stosunków społeczno-ekonomicznych, Warszawa 1963 , s. 37.

16 Stan polskiego posiadania na Polesiu, 1939 r., w: Polesie w polityce..., s. 200.

17 O. Grott, Instytut Badań Spraw Narodowościowych i Komisja Naukowych Badań Ziem Wschodnich w planowaniu polityki II Rzeczypospolitej Polskiej na Kresach Wschodnich, Kraków 2013, s. 201.

18 Przykładem takiej propagandy były niczym nieuzasadnione szacunki liczby szlachty zagrodowej na Wołyniu i Polesiu, sięgającej według Dworakowskiego ponad 300 tys. osób, zob. S. Dworakowski, Szlachta zagrodowa we wschodnich powiatach Wotynia i Polesia. Relacje z terenu, Warszawa 1939. 
zasiedlania Polesia nie wyglądały jednak imponująco. Mimo bardzo niskiej gęstości zaludnienia istotnie brakowało ziem uprawnych. Tereny słabo zasiedlone były w znacznej mierze zajęte przez bagna i mokradła. Ten czynnik, przy faktycznym niepowodzeniu projektu melioracji oraz nadzwyczajnie wysokim przyroście naturalnym miejscowej ludności nie pozostawiał złudzeń co do planów kolonizacji. Ponadto osadnictwo uniemożliwiała zupełna społeczna i gospodarcza nieatrakcyjność Polesia, które było często kojarzone „z najgorszym zakątkiem, zdala od świata i ludzi”"19. Taki przekaz w odniesieniu do Polesia - jako regionu zupełnie oderwanego od cywilizacji - nagminnie występował w polskiej publicystyce i literaturze popularnej ${ }^{20}$.

W tej sytuacji zasięg oddziaływania polskości na przeciętnego Poleszuka prawie w całości zbiegał się z zakresem działalności polskiej administracji. Do pracy społecznej próbowano zaangażować aparat urzędniczy, szkołę oraz wojsko. Kościół katolicki, jednoznacznie kojarzony na ziemiach wschodnich z polskością, nie mógł mieć na Polesiu dużego oparcia $\mathrm{z}$ racji dominującego na tych terenach prawosławia.

Niewątpliwie propagatorem polskości w regionie była głównie ludność napływowa, słabo jednak obeznana w miejscowych realiach. Dla wielu przybyszów z innych części Polski nominacja na Polesie oznaczała swoiste zesłanie. Bardzo często trafiały tam osoby, które skompromitowały się na poprzednim stanowisku. Na niektórych urzędnikach wręcz ciążyły zarzuty natury kryminalnej ${ }^{21}$.

Prawdopodobnie sytuacja zasadniczo nie zmieniła się w drugiej dekadzie dwudziestolecia międzywojennego. Decyzja o przeniesieniu nawet wysokiej rangi urzędnika resortu oświaty z Zagłębia Dąbrowskiego na Polesie w 1935 r. spotykała się z prawdziwym rozgoryczeniem, które wyrazić można jednym zdaniem „jechałem do Brześcia z ciężkim sercem, niechętnie i z musu"22.

Wydaje się, że najbardziej skutecznym - chociaż nietrwałym - środkiem propagowania walorów polskości była służba wojskowa. Poborowych z Polesia zazwyczaj przydzielano do jednostek stacjonujących $w$ bardziej zagospodarowanych centralnych i zachodnich częściach kraju. Dla słabo uświadomionych Poleszuków często była to dwuletnia wycieczka do innego świata. Niewątpliwie część rezerwistów po powrocie do rodzinnych stron ulegała wpływom polskim, które dla konserwatywnego społeczeństwa poleskiego były kojarzone z pańskością. Ze sprawozdań wojskowych wynikało, że „w wojsku Białorusini polonizują się dość szybko, choć

19 Zakład Narodowy im. Ossolińskich, Dział Rękopisów (dalej: ZNiO DR), sygn. 16731/II, mf 35885, Stanisława Cybulska-Białowieska, „Moje wspomnienia (lata 1922-1945)”, s. 2.

20 Zob. П. Ціхарацкі, „Палямук” - аб'ект цыьвілізацыйнай місіі і пакрыуджаны суайчыннік. Праваслаўныя вясковыя жыхары Палескага ваяводства ў польскай папулярнай літаратуры міжваеннага перыяду, „Arche” (2014), nr 7-8.

${ }^{21}$ L. Wasilewski, Wspomnienia 1870-1904 (1914). Fragmenty dziennika 1916-1926, diariusz podróży po kresach 1927, oprac. J. Dufrat, P. Cichoracki, Łomianki 2014, s. 331.

22 ZNiO DR, sygn. 15641/II/t.1, mf 10159, Antoni Zięba, „Pamiętnik pedagogiczny. Wspomnienia i refleksje", t. 1 [lata 1900-1939], s. 285. 
przeciwdziałają temu urlopy, bo koledzy kpią z wielkopańskich zachcianek, do których środowisko zalicza formy obyczajowe i dbałość o wygląd zewnętrzny"23.

Polski socjolog, Józef Obrębski, dość sceptycznie oceniał perspektywy szybkiej asymilacji Poleszuków, widząc ogromny dystans społeczny pomiędzy Poleszukiem-autochtonem i Polakiem. Dla większości przybyłych Polaków miejscowa kultura ludowa była jednoznacznie kojarzona z zacofaniem i dzikością. Przyjęcie polskiej kultury dla przeciętnego Poleszuka wiązało nie tylko z odrzuceniem dotychczasowych wzorców kulturowych, ale również z wyrwaniem ze środowiska wiejskiego ${ }^{24}$. Możliwości ruchliwości społecznej na Polesiu były jednak minimalne.

Zasadniczą alternatywę dla działań polskiej administracji na Polesiu w latach dwudziestych XX w. zaproponowały polskie ugrupowania lewicowe - Polska Partia Socjalistyczna (PPS) i Polskie Stronnictwo Ludowe (PSL) „Wyzwolenie”. Działalność polskiej lewicy na Polesiu w pierwszej dekadzie dwudziestolecia międzywojennego była zresztą doskonałym przykładem szybkiego opanowania terenu dotychczas niemającego jakiejkolwiek tradycji politycznej ${ }^{25}$. Napływowi emisariusze zakładali struktury PPS i „Wyzwolenia” na poleskiej wsi, wywierając silny wpływ na poleskiego chłopa. W swojej agitacji nawoływali do przeprowadzenia szerokich reform społecznych na Kresach, posługując hasłami niemal bolszewickimi ${ }^{26}$.

W kwestii narodowościowej deklarowali równość wszystkich obywateli państwa polskiego bez względu na narodowość i wyznanie. Zarazem podejście PPS w kwestiach narodowych i językowych było nacechowane swoistą ambiwalencją. $\mathrm{Na}$ jednym $\mathrm{z}$ wieców partyjnych w powiecie pińskim poseł PPS Józef Dzięgielewski powiedział, że „ziemia białoruska powinna należeć do Białorusinów”, a jednocześnie nawoływał zebranych do nauki „wszystko jedno w jakim języku, gdyż nauka jest zawsze jednakowa"27.

Polskie ugrupowania lewicowe były zdecydowanymi przeciwnikami zarówno polskiego nacjonalizmu, jak i zbytniego eksponowania narodowych partykularyzmów mniejszości. Stąd nieprzychylnie odnosiły się do zakładania przez mniejszości narodowe swoich własnych stronnictw lewicowych. Na Polesiu głównie ze względów taktycznych lewica polska szeroko posługiwała się językiem rosyjskim podczas agitacji oraz wydawała prasę partyjną w tym języku. Polskość lewicowych ugrupowań nie przeszkadzała w zdobyciu wpływów politycznych na Polesiu, natomiast działalność tych partii, przede wszystkim z powodu radykalizmu społecznego, była nie do zaakceptowania dla administracji państwowej. Prawdopodobnie aktywność

${ }^{23}$ K. Gomółka, Białorusini w II Rzeczypospolitej, Gdańsk 1992, s. 142.

24 J. Obrębski, Polesie, red. A. Engelking, Warszawa 2007, s. 536.

25 P. Cichoracki, Województwo poleskie 1921-1939. Z dziejów politycznych, Łomianki 2014, s. 130.

${ }^{26}$ E. Massis, Próby wykształcenia tożsamości narodowej u ludności słowiańskiej na Polesiu w pierwszych latach II Rzeczypospolitej Polskiej (1920-1928), „Adeptus” (2015), nr 5, s. 5.

27 Państwowe Archiwum Obwodu Brzeskiego (dalej: PAOB), sygn. f. 2001, op. 4, d. 1998, Meldunek sytuacyjny Nr 18 z dnia 25.1.1925 z Poleskiego Urzędu Wojewódzkiego do Ministerstwa Spraw Wewnętrznych, k. 57. 
tych podmiotów politycznych miała minimalny wpływ na proces uświadomienia narodowego poleskiego chłopa. Zatem można zaryzykować tezę, że rozpolitykowanie terenu Polesia ostatecznie wywarło negatywny wpływ na perspektywy jego polonizacji, ponieważ $\mathrm{w}$ ten sposób godzono $\mathrm{w}$ struktury państwowe, które niejako były promotorami polskości na tych terenach.

Czynnik zacofania cywilizacyjnego odegrał pierwszoplanową rolę $\mathrm{w}$ niepowodzeniu akcji polonizacyjnej na Polesiu. Fala przemian cywilizacyjnych wdrażanych przez państwo polskie $\mathrm{w}$ tym rejonie $\mathrm{w}$ dwudziestoleciu międzywojennym nie mogła zapewnić miejscowej ludności szerokich możliwości awansu społecznego. Zapowiadana szybka polonizacja Poleszuków w przypadku poszczególnych osób przybierała co najwyżej charakter akulturacji. Warszawa nieco bezkrytycznie była przekonana o postępach polonizacji po zapoznaniu się z pełnymi optymizmu sprawozdaniami nadchodzącymi z Brześcia w drugiej dekadzie okresu międzywojennego. Mimo szeroko zakrojonej akcji polonizacyjnej związek emocjonalny poleskiego chłopa z państwem polskim pod koniec lat trzydziestych XX w. był wciąż nikły.

\section{Rosyjski projekt narodowy}

Polskie Kresy Wschodnie w myśli politycznej Cesarstwa Rosyjskiego uznawane były za zachodnie rubieże tegoż Imperium, będąc w okresie zaborów terenem polsko-rosyjskiej rywalizacji. Po traktacie w Rydze wielu zwolenników rosyjskiej ideologii imperialnej wbrew swojej woli znalazło się w granicach odrodzonej Polski. Bycie wyznawcą idei ,jednej i niepodzielnej Rosji” oraz krzewienie rosyjskości było odbierane jako zamach na terytorialną integralność II Rzeczypospolitej.

Wskutek działań rusyfikacyjnych w Imperium Rosyjskim część autochtonicznej ludności Polesia uważała siebie za Rosjan. Wpływy mocno zrusyfikowanego elementu drobnomieszczańskiego były szczególnie widoczne w Dawidgródku i jego okolicach, gdzie miejscowi Rosjanie stanowili większość w radzie miejskiej ${ }^{28}$. W tym miejscu warto przytoczyć krótkie, ale klarowne opisanie tejże społeczności o zapatrywaniach rosyjskich w Pińsku. „Mieszczanin piński gardzi chłopskim ubraniem, chłopskimi zwyczajami oraz językiem. Lubi śpiewać wulgarne piosenki rosyjskie i uważa siebie za Rosjanina. Jego mentalność rzecz jasna nie ma nic wspólnego z rosyjskością, zaś zasadnicze znaczenie odgrywa tu sympatia wobec Rosjan"29.

Idea „wielkiego narodu rosyjskiego" na Polesiu w okresie międzywojennym wciąż nie była anachronizmem. Wydawana w Pińsku rosyjskojęzyczna gazeta „Pod Niebem Polesia” w przededniu spisu ludności w 1931 r. wzywała „każdego polskiego obywatela narodowości rosyjskiej (Wielkorusa, Białorusa, Małorusa)

28 А. Ильин, Всплеск русского движения в Давид-Городке в 1928-1931 годах, w: Берасиейскі хранограф: зб. навук. праи., ред. М. Часноўскі, вып. 4, Брэст 2004, s. 142.

29 Ф. Одрач, Наше Полісся, „Пам’ятки України” (2002), nr 3-4, s. 15. 
powiedzieć, że jego językiem ojczystym jest rosyjski”30. Polescy działacze Rosyjskiego Zjednoczenia Narodowego (RZN) traktowali naród rosyjski jeszcze szerzej, włączając do niego Ukraińców, Białorusinów, Rosjan, Rusinów i Poleszuków ${ }^{31}$. Działacze Związku Organizacji Mniejszości Rosyjskiej w Polsce, a zarazem zwolennicy bardziej nowoczesnej definicji rosyjskości - tylko ten jest Rosjaninem, kto świadomie uznaje siebie za przynależnego do narodu rosyjskiego - nie posiadali na Polesiu dużych wpływów ${ }^{32}$.

Mimo wszystko wielu Rosjan na Polesiu potrafiło dobrze się odnaleźć w nowej rzeczywistości. Znamienny jest fakt, iż Rosjanie dość często byli nadreprezentowani w aparacie państwowym, szczególnie na jego niższym szczeblu. Jeszcze w 1932 r. spośród dwunastu urzędników starostwa łuninieckiego, ośmiu przyznawało się do narodowości rosyjskiej ${ }^{33}$. W rozmowach $\mathrm{z}$ interesantami tacy urzędnicy posługiwali się językiem rosyjskim, co w mniemaniu władz polskich sprzyjało rusyfikacji Poleszuków.

Ponadto na Polesiu zamieszkiwało kilkunastu wybitnych działaczy rosyjskich. Najważniejszym politycznym osiągnięciem Rosjan było zdobycie w pińskim okręgu wyborczym w 1928 r. mandatu posła na Sejm przez Pawła Korola. Sukces listy rosyjskiej okazał się nieprzewidywalny dla władz ${ }^{34}$. Środowiska rosyjskie natomiast otrzymały argument dla demagogicznych twierdzeń o Polesiu jako o najsilniejszym ośrodku życia rosyjskiego w Polsce. Padały również niczym nieuzasadnione tezy dotyczące milionowej społeczności rosyjskiej w Polsce oraz zwartej masy Rosjan zamieszkującej Polesie ${ }^{35}$.

Popularności haseł „jednej i niepodzielnej Rosji” mocno sprzyjała powszechność języka rosyjskiego w przestrzeni publicznej. Rosyjski, mimo utraty statusu języka urzędowego, wciąż miał wysoką pozycję społeczną. Przeciętny Poleszuk był przekonany, że władanie językiem rosyjskim jest oznaką wykształcenia. Po rosyjsku mógł porozumieć się z miejscowym Żydem, gdyż nawet pod koniec dwudziestolecia międzywojennego Żydzi polescy chętnie posługiwali się tym językiem ${ }^{36}$. Wreszcie w sposób dosyć zjadliwy komentowano w warszawskim dzienniku „Za Swobodu!" kolportaż polskiej prasy w języku rosyjskim na Polesiu. Zdaniem poleskiego ziemianina Aleksandra Kisłowskiego, ten fakt był tożsamy z przyznaniem się do obecności Rosjan w Polsce oraz ich rosnącymi wpływami ${ }^{37}$.

30 „Под небом Полесья” 6.11.1931, nr 6, s. 1.

31 В. Мисиюк, Исследование начиональных процессов в Восточной Европе на примере Полесского воеводства (1921-1939 г2.), „Перекрёстки” (2007), nr 3-4, s. 236.

32 В. Швайко, Русская диаспора в Польше в 20-30 г2. ХХв., „Диаспоры” (2004), nr 2, s. 198.

33 Artykut „Akcja nacjonalistów rosyjskich na Polesiu” z gazety „Jutro pracy”, „Biuletyn Polsko-Ukraiński” 2.10.1938, nr 37, s. 412.

${ }^{34}$ P. Cichoracki, Województwo poleskie..., s. 264.

${ }^{35}$ Referat sporządzony przez Wydział Bezpieczeństwa Urzędu Wojewódzkiego Poleskiego o ruchu $i$ wplywach rosyjskich na Polesiu z 27 VI 1933, w: Polesie w polityce..., s. 80.

36 L. Sobociński, Zdobywamy zjudaizowany Wschód, „Tęcza” listopad 1938, nr 11, s. 33.

37 Польские газеты на русском языке, „За Свободу!” 15.02.1928, nr 37, s. 3. 
Cerkiew prawosławna na Polesiu była instytucją prawie w całości rosyjskojęzyczną. Szczególnie interesujący jest fakt, że językiem rosyjskim w swojej praktyce liturgicznej posługiwali się również „sekciarze” - przedstawiciele nowych ruchów protestanckich, którzy odpadli od prawosławia. Ten stan rzeczy zaczął stopniowo się zmieniać w latach trzydziestych XX w., kiedy to wojewoda poleski Wacław Kostek-Biernacki podjął działania w kierunku polonizacji Cerkwi. Naturalną zaporę w tych planach stanowił niższy kler prawosławny, wychowany w tradycjach Rosji carskiej i słabo znający język polski. Wśród księży prawosławnych na Polesiu również nie brakowało jednostek o daleko idących zapatrywaniach rosyjskich. W 1928 r. w okresie agitacji wyborczej ta grupa działała wręcz wbrew woli pińskiego arcybiskupa Aleksandra, który zalecił wesprzeć kandydatów Bezpartyjnego Bloku Współpracy z Rządem (BBWR). Niektórzy duchowni prawosławni z ambony wprost nawoływali do głosowania na kandydatów RZN oraz rozdawali odezwy przedwyborcze tego ugrupowania ${ }^{38}$. Ponadto zjawiskiem charakterystycznym dla tej grupy duchowieństwa prawosławnego była głęboko zakorzeniona nostalgia za Imperium Rosyjskim i kult cara. Starosta drohicki w listopadzie 1932 r. meldował, że z inicjatywy proboszcza Rusieckiego i przy udziale miejscowej ludności we wsi Lachowicze odbyło się żałobne nabożeństwo za cara Mikołaja i dom Romanowów ${ }^{39}$.

W warunkach prawie całkiem spolonizowanego systemu oświatowego na Polesiu Rosjanie próbowali otwierać prywatne zakłady edukacyjne. Prywatne gimnazja rosyjskie istniały w Brześciu, Łunińcu i Pińsku. Dwie ostatnie placówki nie przetrwały długo, natomiast w latach 1921-1939 w Brześciu działała prywatna rosyjska szkoła powszechna i gimnazjum. Proces nauczania w tych placówkach bezpośrednio nawiązywał do zasad panujących w Imperium Rosyjskim. Należy zatem przyjąć, iż gimnazjum było swoistą ostoją ancien régime, miejscem podtrzymania i krzewienia rosyjskości. Zwłaszcza w latach trzydziestych XX w. szkoła ta była prawdopodobnie najważniejszym rosyjskim ośrodkiem na Polesiu ${ }^{40}$.

Ukraińska społeczność Brześcia w 1923 r. próbowała przekształcić te placówki według własnych planów. Chciano wprowadzić język ukraiński do systemu nauczania na równi z rosyjskim. Ostatecznie pomysł ten spotkał się z ogromnym oporem ze strony Rosjan i do zmian nie doszło ${ }^{41}$. Od 1924 r. opiekę nad gimnazjum rosyjskim przyjęło Rosyjskie Towarzystwo Dobroczynności, którego celem było podtrzymywanie kulturalno-oświatowej działalności mniejszości rosyjskiej w Polsce. Oddziały i biblioteki Towarzystwa działały prawie wyłącznie w ośrodkach miejskich, stąd pozyskanie poleskiego chłopa dla idei rosyjskiej wydawało się rzeczą mało prawdopodobną.

38 PAOB, sygn. f. 1, op. 9, d. 503, Duchowni prawosławni - agitacja przedwyborcza, k. 7.

39 PAOB, sygn. f. 1, op. 9, d. 2202, Nabożeństwa żałobne za cara Mikołaja, k. 7.

40 Archiwum Akt Nowych (dalej: AAN), Urząd Wojewódzki w Brześciu nad Bugiem, sygn. 19, Sprawozdanie sytuacyjne $\mathrm{nr} 4$ za kwiecień 1934 r., k. 29.

${ }_{41}$ М. Монтвилов, Русская гимназия в Бресте на Буге 1919-1939 г2., Ним-Брест-Минск 1996, s. 40 . 
Spoiwem ideologicznym dla zwolenników rosyjskiego projektu narodowego na Polesiu była nostalgia za Imperium Rosyjskim oraz wiara w szybki powrót rządów rosyjskich na "terenach utraconych", do których niewątpliwie zaliczano Polesie. Można zatem zaryzykować tezę, że stabilizowanie się władzy bolszewickiej na Kremlu z roku na rok wywoływało coraz większą frustrację oraz zanik działalności środowisk rosyjskich w Polsce. Lokalnym uwarunkowaniem była zmiana na stanowisku wojewody poleskiego w 1932 r. Jest rzeczą znaną, że wojewoda Kostek-Biernacki wobec Rosjan nie żywił nawet najmniejszej sympatii ${ }^{42}$. Już w 1934 r. na łamach gazety „Nasze Wremja” ukazał się reportaż z Łunińca na temat opłakanego stanu sprawy rosyjskiej na poleskiej prowincji ${ }^{43}$. Zapewne poglądy radykalnej części działaczy rosyjskich na Polesiu ewoluowały w kierunku tzw. smieny wiech („zmiany drogowskazów”). Pośrednio świadczą o tym losy uczestników nieformalnego kółka młodzieży rosyjskiej w Pińsku. Jego nieoficjalny lider Michał Kluczenowicz, zanim został wydalony z Polski w 1933 r. jako „uciążliwy cudzoziemiec”, ubiegał o możliwość legalnego wyjazdu do Związku Sowieckiego. Z kolei monarchista Bazyli Korotyszewski po wrześniu 1939 r. szybko znalazł pracę w systemie propagandy nowej władzy ${ }^{44}$.

\section{Projekty narodowe białoruski i ukraiński}

W okresie międzywojennym Polesie stawało się terenem narodowościowych roszczeń Białorusinów i Ukraińców. Były to społeczności bezpaństwowe o wybitnie chłopskiej strukturze społecznej, więc wydaje się zasadne pokusić się o porównanie białoruskich i ukraińskich wpływów na Polesiu. Należy zacząć od stwierdzenia, że Polesie w dwudziestoleciu międzywojennym nie było obszarem ostrej rywalizacji Białorusinów i Ukraińców. W sytuacjach potencjalnie konfliktowych zazwyczaj dochodziło do kompromisu. Przykładem takiego porozumienia był podział okręgów wyborczych pomiędzy Białorusinami i Ukraińcami podczas kampanii parlamentarnej $1922 \mathrm{r}$. W rezultacie pierwsze miejsca na listach Bloku Mniejszości Narodowych (BMN) w brzeskim okręgu wyborczym oddano Ukraińcom, a w pińskim - Białorusinom. Przy tym należy zastrzec, że powyższa ugoda $\mathrm{z}$ punktu widzenia obu stron nie przesądzała o narodowości mieszkańców spornego terytorium ${ }^{45}$.

Mimo wszystko interesy ruchów białoruskiego i ukraińskiego na Polesiu niezbyt często krzyżowały się między sobą. Wynikało to głównie z różnic potencjalnego

42 P. Cichoracki, Droga ku anatemie. Wacław Kostek-Biernacki (1884-1957), Warszawa 2009, s. 288.

43 Вызываем Лунинеи!!, „Наше время” 24.10.1934, nr 249, s. 4.

44 Zob. A. Ильин, Шалаш поэтов, „Гістарычная брама: гісторыя і культура Палесся” (2004), nr 1, http://brama.brestregion.com/nomer22/artic21.shtml (dostęp: 29.05.2017).

45 А. Пашкевіч, Нацььянальныя працэсы у Палескім ваяводстве у 1920-я г2. праз прызму вынікаў выбарчых кампаній у польскі парламент, „Arche” (2013), nr 4, s. 114. 
oddziaływania białoruskiej i ukraińskiej idei narodowej na poleskiego chłopa. Polesie dla Ukraińców było terenem trudno dostępnym nie tylko z powodu ukształtowania terenu, ale przede wszystkim jego peryferyjnego położenia wobec Galicji Wschodniej. Młody i strukturalnie nierozwinięty ruch białoruski nie dysponował natomiast wielkimi zasobami, mając na Polesiu bardzo ograniczone możliwości działania zarówno terytorialnie, jak i organizacyjnie. W 1922 r. Białorusini wydali wręcz mizerne środki finansowe na cele agitacji przedwyborczej w województwie poleskim w porównaniu z nowogródzkim ${ }^{46}$. Świadczy to, że nie tylko nie mieli pieniędzy, ale również swojego aktywu na Polesiu. Niedociągnięcia Białorusinów zręcznie wykorzystała PPS, zdobywając na Pińszczyźnie trzy mandaty poselskie. $\mathrm{W}$ okręgu brzeskim natomiast zwyciężyła lista BMN na czele $\mathrm{z}$ dwoma kandydatami narodowości ukraińskiej ${ }^{47}$.

Kolejnym sprawdzianem żywotności ruchów białoruskiego i ukraińskiego na Polesiu stała akcja zbierania podpisów w sprawie otwarcia państwowych szkół z białoruskim lub ukraińskim językiem wykładowym. Szczególne jej natężenie miało miejsce w roku szkolnym 1925/1926, po wejściu w życie tzw. ustawy „lex Grabski”48. W tym okresie Ukraińcom udało się zebrać 6239 podpisów, zaś Białorusinom tylko 1343. Większość ukraińskich deklaracji pochodziła z trzech powiatów - brzeskiego, kobryńskiego i drohickiego. Dodatkowo w powiecie kosowskim, narodowościowo raczej białoruskim, Ukraińcom udało się namówić 116 osób. Białoruska akcja szkolna właściwie ograniczyła się do powiatu prużańskiego ${ }^{49}$.

Wreszcie należy przytoczyć opinię wojewody Jana Krahelskiego z sierpnia 1932 r. w sprawie rozwoju stosunków narodowościowych na Polesiu. Warto jednak pamiętać, że ruch białoruski w tamtym czasie funkcjonował w zasadniczo odmiennych realiach politycznych. Wojewoda równocześnie scharakteryzował wyniki powszechnego spisu ludności 1931 r. jako niemal humorystyczne, gdyż wykazały olbrzymie obniżenie poziomu świadomości narodowej. Według Krahelskiego liczba Ukraińców na Polesiu została mocno zaniżona. Wojewoda sygnalizował poważne postępy agitacji ukraińskiej wśród ludności południowej części Polesia, która już w tym czasie posiadała poczucie przynależności narodowej. Jednocześnie wyrażał niezbyt pochlebną opinię o Białorusinach, przewidując zanik ruchu białoruskiego na Polesiu. Sądził, że:

${ }^{46}$ Ibidem, s. 116.

47 Szczegółowo wyniki kampanii wyborczej 1922 r. na Polesiu omawiał: P. Cichoracki, Województwo poleskie..., s. 127-133.

48 Ustawa z dnia 31 lipca 1924 r. zawierająca niektóre postanowienia o organizacji szkolnictwa (potocznie „lex Grabski”) - ustawa regulująca kwestię szkolnictwa dla mniejszości narodowych, uchwalona w 1924 r. Wprowadziła szkoły dwujęzyczne (utrakwistyczne) jako podstawowy typ szkół. W opinii mniejszości narodowych celem przyjęcia ustawy było wynarodowienie uczniów niepolskiego pochodzenia.

49 P. Cichoracki, Województwo poleskie..., s. 48. 
Ruch białoruski, zakrojony terytorialnie na bardzo szeroką skalę, przy bardzo niskim, na całym tym terytorium, rozwoju uświadomienia narodowego, przy braku własnej inteligencji i braku własnego dorobku kulturalnego, może nie sprostać zadaniom, jakie sam sobie zakreśla i pozostawiony samemu sobie - o ile praca państwowa polska będzie się rozwijała w szybkim tempie - albo zamrze całkowicie, albo będzie zmuszony bardzo wydatnie skurczyć swe aspiracje terytorialne... ${ }^{50}$.

Natomiast narodowo uświadomieni Białorusini i Ukraińcy nie mieli wątpliwości, że Polesie jest częścią białoruskiego bądź ukraińskiego narodowego terytorium. Wśród tego rodzaju działaczy Poleszuk był zaliczany do Białorusina lub Ukraińca przede wszystkim ze względów językowych. Posługiwanie się gwarą zbliżoną do języka białoruskiego lub ukraińskiego uznawano za cechę obiektywną, która niejako przesądzała o przynależności narodowej jednostki. Kwestia niewyrobionej świadomości narodowej Poleszuków w tym przypadku nie odgrywała żadnej roli. Język nawet w odmianie gwarowej w przekonaniu budzicieli świadomości narodowej był wartością, którą należało pielęgnować. Białoruski działacz a zarazem unicki ksiądz Wacław Onoszko w swojej parafii w powiecie stolińskim robił uwagi niesfornej młodzieży z powodu używania polszczyzny zamiast „ojczystego języka białoruskiego"51. Ukraińska działaczka Helena Kisielewska, kilkakrotnie podróżująca w latach trzydziestych XX w. po Polesiu, opatrzyła swoją relację z terenu dość charakterystycznym epilogiem: „Jestem przekonana, że ta część naszego narodu, chociaż daleka, ale mocno związana z nami krewnie, językowo i historycznie, wcześniej czy później złączy się z nami duchowo - tak musi się stać! - w jednym ukraińskim morzu" 52 .

W realiach województwa poleskiego akcja narodowościowa mogła znaleźć swojego odbiorcę tylko w połączeniu z hasłami radykalnych przemian społecznych. $\mathrm{Na}$ ubogiej poleskiej wsi tego typu retoryka padała na podatny grunt i w krótkim czasie mogła zmobilizować liczną grupę zwolenników. Większość białoruskich i ukraińskich działaczy na Polesiu sympatyzowała lub należała do radykalnych ugrupowań lewicowych. Reprezentantką ruchu białoruskiego była Białoruska Włościańsko-Robotnicza Hromada (BWRH), która z wiadomych przyczyn nie przetrwała tam zbyt długo. Jej odpowiednikiem po stronie ukraińskiej był Sel-Rob. W opinii władz polskich obydwie te organizacje były tylko i wyłącznymi legalnymi przybudówkami partii komunistycznej. Na Polesiu działała głównie Komunistyczna Partia Zachodniej Białorusi (KPZB), chociaż w drugiej dekadzie dwudziestolecia międzywojennego południowe peryferie województwa poleskiego opanowały placówki Komunistycznej Partii Zachodniej Ukrainy (KPZU) ${ }^{53}$.

50 PAOB, sygn. f. 1, op. 9, d. 2253, Memoriał Pana wojewody Jana Krahelskiego do Pana Ministra spraw wewnętrznych o stosunkach narodowościowych na Polesiu, sierpień 1932, k. 3-7.

51 PAOB, sygn. f. 1, op. 10, d. 2229, Akcja unijna - informacje, grudzień 1934, k. 11.

52 О. Кисілевська, По рідному краю, Коломия 1935, s. 128.

53 P. Cichoracki, Komuniści na Polesiu w latach 1921-1939, Łomianki 2016, s. 29. 
Pod względem politycznym ukraiński ruch na Polesiu był jednak bardziej zróżnicowany. Obecni w nim działacze o poglądach umiarkowanych skupiali się przede wszystkim wokół placówek „Proświty” w Brześciu i Kobryniu. Było to grono sympatyków Ukraińskiego Narodowo-Demokratycznego Zjednoczenia (UNDO) i tzw. petlurowców - członków ukraińskich formacji wojskowych pod dowództwem atamana Petlury. Tarcia ideologiczne w kręgach ukraińskich często negatywnie wpływały na działalność „Proświty”, m.in. w placówce kobryńskiej miał miejsce zatarg dotyczący prenumeraty prasy ukraińskiej. Sel-robowska mniejszość chciała prenumerować lewicowe gazety „Switło” i „Nasze Żyttia”, natomiast większość chciała czytać „Diło” - oficjalny organ prasowy $\mathrm{UNDO}^{54}$.

Białoruskie partie o orientacji narodowo-demokratycznej miały tylko pojedynczych sympatyków na terenie Polesia. Białoruska Chrześcijańska Demokracja próbowała założyć placówki w powiecie prużańskim. Działania te pozostały bez skutku ${ }^{55}$.

Białoruska i ukraińska działalność kulturalno-oświatowa na Polesiu była prowadzona w ramach Towarzystwa Szkoły Białoruskiej i „Proświty”. Obydwie organizacje $\mathrm{w}$ swoich założeniach próbowały zaproponować alternatywę wobec polonizacji systemu oświatowego i życia publicznego na Polesiu. W 1928 r. miał miejsce lawinowy wzrost liczby placówek „Proświty” na poleskiej wsi z 18 do $112^{56}$. Prawdopodobnie założone kółka w większości znajdowały się pod wpływem sympatyków i członków Sel-Robu oraz komunistów. Kółka „Proświty” zakładano przede wszystkim w powiatach brzeskim, kobryńskim i drohickim, więc na tych terenach organizacja miała charakter masowy. Wschodnie połacie województwa poleskiego pozostały poza jej zasięgiem.

Niewątpliwie gwałtowny wzrost liczby placówek „Proświty”, przepełnionych elementem radykalnym, sprzyjał upolitycznieniu organizacji, zaś działania kulturalno-oświatowe odsuwano na dalszy plan. Ostatecznie doszło do poważnego zatargu pomiędzy centralą „Proświty” w Brześciu a kierownictwami poszczególnych placówek na tle poglądów politycznych i dalszego rozwoju organizacji. Pod naciskiem władz podniesiono składkę członkowską z 50 groszy do 3 złotych, co w założeniu członków zarządu głównego miało usunąć z organizacji element radykalny i doprowadzić do uzdrowienia całej sytuacji. W rzeczywistości konflikt znacząco osłabił wpływy „Proświty” na poleską wieś. Liczba członków wiejskich placówek od 1930 r. zaczęła stopniowo maleć, a od 1933 r. organizacja znajdowała się już w stanie wegetacji ${ }^{57}$.

${ }^{54}$ AAN, Urząd Wojewódzki w Brześciu nad Bugiem, sygn. 9, Meldunek sytuacyjny nr 22 od 27/V. do 2/VI.1928 roku, k. 120.

55 Э. Мазько, Палессе у каниэпиыях беларускіх палітычных партый Заходняй Беларусі, w: Загароддзе-3, ред. Ф. Клімчук, А. Энгелькінг, В. Лабачэўская, Мінск 2001, s. 149.

56 В. Місіюк, Просвіта на Поліссі (1923-1938 рр.), „Наукові записки Національного університету «Острозька академія»: Історичні науки” (2013), nr 21, s. 139.

57 Raport sporządzony przez Wydział Bezpieczeństwa Urzędu Wojewódzkiego Poleskiego o rozwoju ukraińskiego ruchu narodowościowego na Polesiu w latach 1918-1933, w: Polesie w polityce..., s. 145. 
Zapewne z punktu widzenia administracji państwowej kółka „Proświty” były tylko i wyłącznie parawanem dla działalności określanej jako wywrotowa. W tym miejscu nasuwa się pytanie: czy krótki żywot „Proświty” mógł istotnie wpłynąć na wzrost świadomości narodowej wśród Poleszuków? Pośrednio na korzyść pozytywnej odpowiedzi świadczą słowa mieszkańca Drohiczyna w liście do senatorki Kisielewskiej z kwietnia 1934 r.: „uświadomiliśmy kim jesteśmy jak pojawiły się u nas ukraińskie biblioteki i czytelnie, jak zaczęliśmy czytać ukraińskie gazety i książki” ${ }^{58}$.

Generalnie według podobnego schematu przebiegał rozwój Towarzystwa Szkoły Białoruskiej na Polesiu. Placówki organizacji zakładano głównie w dwóch północnych powiatach województwa - kosowskim i prużańskim. Wskutek faktycznej nieobecności na Polesiu umiarkowanych działaczy białoruskich, od samego początku w Towarzystwie wziął górę element bardziej radykalny. Prawdopodobnie po rozwiązaniu BWRH wiosną 1927 r. część jej byłych członków zasiliła szeregi Towarzystwa. Zanik działalności organizacji na Polesiu miał miejsce w $1933 \mathrm{r}$.

Obecność w ukraińskim ruchu na Polesiu działaczy o poglądach centroprawicowych znalazła swoje odzwierciedlenie również w pracy na rzecz ukrainizacji Cerkwi prawosławnej. Członkowie Ukraińskiego Komitetu Obywatelskiego na Polesiu złożyli do pińskiego arcybiskupa Aleksandra list z projektem wykorzystania języka ukraińskiego $\mathrm{w}$ życiu cerkiewnym. Hierarcha dość przychylnie zareagował na tę propozycję, uzależniając jednak jej wdrażanie w życie od woli wiernych i lokalnych uwarunkowań w poszczególnych parafiach ${ }^{59}$. W styczniu 1928 r. w Brześciu odbył się Ukraiński Zjazd Cerkiewny, który zażądał utworzenia odrębnej diecezji na czele z biskupem narodowości ukraińskiej i ukraińskim językiem liturgicznym ${ }^{60}$.

Polesie w okresie międzywojennym było niejako predestynowane do ekspansji ruchów białoruskiego i ukraińskiego. Taki scenariusz w 1923 r. zakładała również administracja państwowa. Poleski wojewoda Stanisław Downarowicz przypuszczał, że czynniki białoruski i ukraiński mogą podać sobie rękę nad Prypecią w przypadku braku konsekwencji i determinacji ze strony władz II Rzeczypospolitej ${ }^{61}$. Dwudziestolecie międzywojenne miało stać się swoistym oknem możliwości dla projektów białoruskiego i ukraińskiego na Polesiu. Rzeczywistość okazała się zupełnie inna. Region pozostał na uboczu wpływów tych dwóch nacji. Narodowa agitacja, najczęściej ściśle związana z działalnością radykalnych stronnictw lewicowych, była w sposób bezwzględny zwalczana przez policję i aparat bezpieczeństwa.

\footnotetext{
58 Biblioteka Narodowa (dalej: BN), mf 69743, Materiały po Olenie Kisielewskiej, k. 854.

59 PAOB, sygn. f. 1, op. 9, d. 330a, Ukraiński Komitet Obywatelski, marzec 1928 r., k. 83.

60 В. Мисиюк, Национальные процессы и церковь в Полесском воеводстве (1921-1939 г2.), „Перекрёстки” (2009), nr 1-2, s. 227.

${ }^{61}$ Program wojewody poleskiego Stanisława Downarowicza..., s. 25.
} 


\section{Zamiast epilogu. Wacław Kostek-Biernacki i kwestia narodowościowa na Polesiu w latach trzydziestych XX wieku}

Może się wydawać, że kresem względnej rywalizacji projektów narodowych był wrzesień 1939 r. W rzeczywistości wyraźne załamanie agitacji narodowej w regionie można zaobserwować już na początku 1933 r. Nowy wojewoda poleski, Wacław Kostek-Biernacki, będąc przekonanym zwolennikiem obozu piłsudczykowskiego, równocześnie zasadniczo odcinał się od programowych założeń polityki narodowościowej rządów sanacyjnych. Ideą przewodnią jego polityki miało być bezwzględne narodowe ujednolicenie państwa polskiego. Polesie stało się swoistym poligonem dla wdrażania takich właśnie pomysłów.

Wychodząc z powyższego założenia, Kostek-Biernacki był sceptycznie nastawiony do prób porozumienia z mniejszościami narodowymi, a zwłaszcza z Ukraińcami. Szczególnie negatywnym punktem odniesienia był „program wołyński” Henryka Józewskiego. Należy podkreślić, że w opinii Kostka-Biernackiego wszelkie odmiany federacji były rozwiązaniem fikcyjnym.

Ale na federację nas nie stać. Sądzę, że każdy, kto podniósłby w Polsce tę myśl - tak klęskową dla jednolitości, a więc siły państwa, uważany byłby za wielkiego szkodnika przez wszystkie sfery społeczeństwa polskiego, z wyjątkiem jedynie komunistów, pracujących dla państwa rosyjskiego. W interesie swojej egzystencji Rzeczpospolita Polska musi być i będzie jednolitym organizmem, nigdy zaś syjamskim okazem biologicznym, kwalifikującym się do panopticum rzeczy i do pośmiewiska słabości, jak b. Austro-Węgry

- pisał wojewoda ${ }^{62}$.

Pochodzący z kręgów wojskowych płk Kostek-Biernacki skupił w swoich rękach prawie nieograniczoną władzę na Polesiu aż do września 1939 r. ${ }^{63}$ Funkcję kierownika referatu społeczno-politycznego w województwie objął osobisty adiutant wojewody, Kazimierz Rolewicz. „Koszarowe porządki” w równym stopniu zostały przeniesione na życie publiczne. Tego typu styl urzędowania znajdował uznanie wśród poleskiego chłopstwa. Kostek-Biernacki w pewnym sensie kreował własny wizerunek jako surowego, lecz sprawiedliwego „gospodarza Ziemi Poleskiej"64.

Wojewoda dążył do wyeliminowania wszelkich niepolskich wpływów na Polesiu. Pretekstem była działalność komunistyczna prowadzona w placówkach mniejszości narodowych. Białorusini nie posiadali dużych wpływów na Polesiu, natomiast w okresie sprawowania władzy przez Kostka-Biernackiego ruch białoruski całkowicie zamarł. W okresie 1932-1934 na Polesiu nie odnotowano już

\footnotetext{
${ }^{62} \mathrm{P}$. Cichoracki, Memoriał narodowościowy wojewody poleskiego Wacława Kostka-Biernackiego z 8 września 1934 r., „Wrocławskie Studia Wschodnie” (2012), nr 16, s. 129.

${ }^{63}$ Od lutego do września 1937 r. obowiązki wojewody poleskiego pełnił Jerzy de Tramecourt.

64 W. Śleszyński, op. cit., s. 56.
} 
nawet śladów jakiejkolwiek aktywności białoruskiej ${ }^{65}$. Po rozruchach w powiecie koszyrskim rozwiązano ukraiński Sel-Rob, którą uznano za przybudówkę ruchu komunistycznego. Następnie pozamykano placówki „Proświty” pod pretekstem opanowania ich przez element wywrotowy. W grudniu $1933 \mathrm{r}$. w województwie poleskim działał tylko skupiający 48 członków oddział „Proświty” w Brześciu.

Presję zastosowano również wobec ukraińskich placówek gospodarczych na Polesiu. Członków spółdzielni ukraińskich różnymi sposobami nakłaniano do zapisywania się do kooperatyw polskich. Najczęściej policja karała grzywnami wskutek drobnych niedociągnięć w pracy tych placówek. Dodatkowo w niektórych przypadkach padały nieuzasadnione podejrzenia o prowadzenie tam agitacji komunistycznej. Zdarzały się incydentalne przypadki zatrzymywania osób z zewnątrz, przeprowadzających kontrolę ukraińskich placówek na Polesiu. W kwietniu 1934 r. przez policję został zatrzymany i spędził ponad dobę w areszcie rewizor Dmytro Esterniuk ze Lwowa, któremu zarzucano działalność na rzecz KPZU ${ }^{66}$. Ostatecznie spółdzielnie ukraińskie na Polesiu przestały istnieć lub zostały podporządkowane placówkom polskim w $1935 \mathrm{r}$.

$\mathrm{W}$ realiach województwa poleskiego lat trzydziestych XX w. osoby z wyrobioną niepolską świadomością narodową były praktycznie odcięte od instytucjonalnych kanałów komunikacji ze swoimi rodakami. Na Polesie z trudem docierała prasa mniejszościowa, a osoby ją prenumerujące znajdowały się na czarnej liście. Zdarzały się przypadki przeszukiwania takich osób oraz stawiania im zarzutów o prowadzenie działalności wywrotowej. Wywoływało to duże rozgoryczenie, a w poszczególnych przypadkach nawet zamiar emigracji, np. do Argentyny ${ }^{67}$.

Po faktycznym zniszczeniu struktur ruchu ukraińskiego na Polesiu prowadzona była systematyczna praca zapobiegawcza. Uszczelniono południowe i południowo-zachodnie granice województwa przed wpływami ukraińskimi na wzór kordonu sokalskiego ${ }^{68}$. Zalecano używać wszelkich środków prewencyjnych w celu niedopuszczenia agitatorów ukraińskich na teren Polesia ${ }^{69}$. Zdarzały się przypadki zatrzymania, aresztowania i następnie wydalenia $\mathrm{z}$ terenu województwa nawet wędrownych handlarzy narodowości ukraińskiej ${ }^{70}$.

65 PAOB, sygn. f. 1, op. 9, d. 1022, Sprawozdanie sytuacyjne nr 10 za październik 1934 r., k. 59.

${ }^{66}$ PAOB, sygn. f. 1, op. 10, d. 222, Spółdzielnie ukraińskie, zjazd w Brześciu n/B, kwiecień 1934 r., k. 23-25.

${ }^{67} \mathrm{BN}, \mathrm{mf}$ 69743, Materiały po Olenie Kisielewskiej..., k. 878.

${ }^{68}$ Kordon sokalski (od miasta Sokal) - umowny termin na określenie granicy administracyjnej pomiędzy Galicją Wschodnią z jednej strony a Wołyniem i Chełmszczyzną z drugiej. Władze międzywojennej Polski politycznie podtrzymywały istnienie tej nieformalnej granicy w celu zapobieżenia ekspansji ukraińskiego ruchu narodowego z Galicji Wschodniej na pozostałe tereny II Rzeczypospolitej zamieszkiwane przez ludność ukraińską.

${ }^{69} \mathrm{PAOB}$, sygn. f. 2, op. 2, d. 333, Korespondencja brzeskiego starosty powiatowego z Poleskim Urzędem Wojewódzkim z 1VII 1937 r., k. 43.

70 PAOB, sygn. f. 1, op. 10, d. 1519, Penetracja i propaganda ukraińska na Polesiu, grudzień 1938 r., k. 5 . 
Działania prewencyjne podjęto również $\mathrm{w}$ odniesieniu do rzekomych prób rusyfikacji Polesia. Starostom powiatowym nakazano przeciwstawiać się „zupełnie nieświadomej, ale szkodliwej propagandzie rosyjskości”. Należało interweniować w przypadku ujawnienia handlu detalicznego przedmiotami z napisami i sentencjami w języku rosyjskim ${ }^{71}$. Starosta łuniniecki w grudniu 1938 r. meldował do Urzędu Wojewódzkiego w Brześciu, że wydał rozporządzenie w sprawie niedopuszczenia do handlu towarami z napisami w języku rosyjskim. Pretekstem było ujawnienie sprzedaży w sklepikach żydowskich igieł do szycia w opakowaniu $\mathrm{z}$ napisami $\mathrm{w}$ tym języku ${ }^{72}$.

Konsekwencją rządów wojewody Kostka-Biernackiego było całkowity zanik życia narodowościowego na Polesiu. Właściwie nawet najmniejsze próby narodowej agitacji były intepretowane przez władze jako działalność wywrotowa. Zatem należy przyjąć, że działania Kostka-Biernackiego zahamowały postęp procesów narodotwórczych w regionie. Młode pokolenie Poleszuków, które dorastało pod rządami polskimi, w gruncie rzeczy cechowała taka sama bierność pod względem narodowościowym, jak ich ojców i dziadów. Polesie pod koniec lat trzydziestych XX w. pozostawało terenem hermetycznym, słabo podatnym na jakiekolwiek wpływy z zewnątrz.

\section{The problem of nationality on the periphery of Central Eastern Europe. The case of Polesia between the two wars}

\section{Abstract}

The territory of Polesia in the interwar period was an area of competition between the national movements of Belarusian, Polish, Russian, and Ukrainian communities. In the Polesia Province, the scope of activity and intensification of national factors were not the same. An influence of the Belarusian movement was seen only in the north of the province, in the districts of Kosów and Prużana. The more active in Polesia Ukrainian movement was the strongest in southern, and south-western districts: of Brześć on the Bug, Kobryń, and Kamień Koszyrski. Russians were the most successful in the cities of Brześć and Pińsk, and in the eastern part of the region, in the neighbourhood of the towns of Euniniec and Dawidgródek, where influences of the Belarusian and Ukrainian movements were minimal. But the idea of "the great Russian nation" was gradually becoming an anachronism within the borders of the Second Republic of Poland. Poland was an active player in the arena of national affairs in Polesia, as it sought to gain the support of local people through a unification policy of the state apparatus. The apogee of the Polonization action was in 1932-1939, after the office of Polesia voivode was taken by Col. Wacław Kostka-Biernacki. Activists of various national movements in Polesia were actively fought against by the State authorities. The voivodeship administration hampered all non-Polish national agitation among inhabitants of the region. The government of the Second Polish Republic did not succeed in combating civilisational backwardness in Polesia. An average inhabitant of the region was, in the first place, a member of his local rural community and often had no idea that for the State administration he was a Pole, for an Orthodox priest

${ }^{71}$ PAOB, sygn. f. 1, op. 9, d. 108, W sprawie propagandy rosyjskiej, maj 1938 r., k. 18.

72 PAOB, sygn. f. 2002, op. 2, d. 1054, W sprawie propagandy rosyjskiej, grudzień 1938 r., k. 7. 
he was a Russian, and for a radical rural intellectual - a Belarusian or Ukrainian. A passive attitude of the majority of local people towards the question of nationality was still common at the end of the interwar period.

Translated by Grażyna Waluga

\section{Национальный вопрос на окраине Центрально-восточной Европы . Случай Полесья между двумя войнами}

\section{Аннотация}

В межвоенный период в Полесье имело место соперничество на национальной почве между белорусскими, польскими, русскими и украинскими кругами. В Полесском воеводстве диапазон действий и степень интенсивности упомянутых национальных факторов не были однородными. Влияние белорусского движения было заметно только на севере Полесья - в Косовском и Пружанском поветах. У более стихийного украинского движения в Полесье больше всего плацдармов находилось южных и юго-западных поветах - Брестском, Кобринском, а также Каширском. Русские имели самый большой успех в городах - Бресте и Пинске, а также на востоке воеводства в окрестностях Лунинца и Давид-Городка, где влияние белорусского и украинского движений было ничтожно. Однако идея «великого русского народа» в границах Второй Речи Посполитой постепенно становилась анахронизмом.

Польша являлась активным игроком на Полесском национальном поле, пытаясь привлечь местное население посредством унификационных действий государственного аппарата. Полонизационная акция достигла апогея в 1932-1939 годах, после вступления в должность Полесского воеводы полковника Вацлава Костка-Бернацкого. Власть последовательно боролась с деятелями отдельных национальных движений в Полесье. Воеводская администрация активно препятствовала ведению всякой непольской национальной агитации среди полещуков.

Властям Второй Речи Посполитой определенно не удалось преодолеть огромную цивилизационную отсталость в Полесье. Среднестатистический полещук оставался, прежде всего, членом сельской общины и часто не имел понятия, что для государственной администрации - он - поляк, для православного священника - русский, а для радикального сельского интеллигента - белорус или украинец. Пассивная позиция большинства полещуков по национальному вопросу продолжала быть всеобщим явлением к концу межвоенного двадцатилетия.

Перевод Агнешка Поспишиль

\section{Bibliografia}

\section{Archiwalia i rękopisy:}

Archiwum Akt Nowych

Urząd Wojewódzki w Brześciu nad Bugiem (Urząd Wojewódzki Poleski)

Biblioteka Narodowa

Materiały po Olenie Kisielewskiej (mf 69743) 
Państwowe Archiwum Obwodu Brzeskiego

Starostwo Powiatowe Brzeskie (f. 2)

Starostwo Powiatowe Łuninieckie (f. 2002)

Starostwo Powiatowe Pińskie (f. 2001)

Urząd Wojewódzki Poleski (f. 1)

Zakład Narodowy im. Ossolińskich (Dział Rękopisów)

sygn. 15641/II/t.1 (mf 10159), Antoni Zięba, „Pamiętnik pedagogiczny. Wspomnienia i refleksje", t. 1 [lata 1900-1939]

sygn. 16731/II (mf 35885), Stanisława Cybulska-Białowieska, „Moje wspomnienia (lata 1922-1945)”

\section{Prasa:}

„Под небом Полесья”, Пинск 1931

„Наше время”, Вильно-Варшава 1934

„Tęcza”, Poznań 1938

„Biuletyn Polsko-Ukraiński”, Warszawa 1938

\section{Opracowania:}

Cichoracki P., Droga ku anatemie. Wacław Kostek-Biernacki (1884-1957), Warszawa 2009.

Cichoracki P., Działalność wywrotowa w województwach północno-wschodnich II Rzeczypospolitej Polskiej - jedno z następstw Wielkiej Wojny, w: Wojna i ludzie. Społeczne aspekty I wojny światowej w Europie Wschodniej, red. D. Michaluk, Ciechanowiec 2015.

Cichoracki P., Komuniści na Polesiu w latach 1921-1939, Łomianki 2016.

Cichoracki P., Memoriat narodowościowy wojewody poleskiego Wacława Kostka-Biernackiego z 8 września 1934 r., „Wrocławskie Studia Wschodnie” (2012), nr 16.

Cichoracki P., Województwo poleskie 1921-1939. Z dziejów politycznych, Łomianki 2014.

Ciesielski S., Kresy Wschodnie - dynamika przemian narodowościowych, w: Kresy Wschodnie II Rzeczypospolitej. Przekształcenia struktury narodowościowej 1931-1948, red. S. Ciesielski, Wrocław 2006.

Drugi powszechny spis Rzeczypospolitej Polskiej z dn. 9 XII 1931 r. Mieszkania i gospodarstwa domowe. Ludność. Stosunki zawodowe. Województwo Poleskie, Warszawa 1938.

Dworakowski S., Szlachta zagrodowa we wschodnich powiatach Wotynia i Polesia. Relacje $z$ terenu, Warszawa 1939.

Gierowska-Kałłaur J., Zarząd Cywilny Ziem Wschodnich (19 lutego 1919 - 9 września 1920), Warszawa 2003.

Gomółka K., Białorusini w II Rzeczypospolitej, Gdańsk 1992.

Grott O., Instytut Badań Spraw Narodowościowych i Komisja Naukowych Badań Ziem Wschodnich w planowaniu polityki II Rzeczypospolitej Polskiej na Kresach Wschodnich, Kraków 2013.

Krysiński A., Liczba i rozmieszczenie Ukraińców w Polsce, „Sprawy narodowościowe” (1928), nr 6.

Massis E., Próby wykształcenia tożsamości narodowej u ludności słowiańskiej na Polesiu w pierwszych latach II Rzeczypospolitej Polskiej (1920-1928), „Adeptus” (2015), nr 5.

Michaluk D., Białoruska Republika Ludowa 1918-1920: u podstaw białoruskiej państwowości, Toruń 2010.

Obrębski J., Polesie, red. A. Engelking, Warszawa 2007. 
Pierwszy powszechny spis Rzeczypospolitej Polskiej z dnia 30 września 1921 roku. Mieszkania. Ludność. Stosunki zawodowe. Województwo Poleskie, Warszawa 1926.

Polesie w polityce rządów II Rzeczypospolitej, red. W. Śleszyński, Białystok-Kraków 2009.

Protokoły i raporty zebrań wojewodów i starostów - województwo poleskie, red. W. Śleszyński, Kraków 2014.

Śleszyński W., Województwo poleskie, Kraków 2014.

Tomaszewski J., Z dziejów Polesia 1921-1939. Zarys stosunków społeczno-ekonomicznych, Warszawa 1963.

Wasilewski L., Sprawa Kresów i mniejszości narodowych w Polsce, Warszawa 1925.

Wasilewski L., Wspomnienia 1870-1904 (1914). Fragmenty dziennika 1916-1926, diariusz podróży po kresach 1927, oprac. J. Dufrat, P. Cichoracki, Łomianki 2014.

Винниченко І., Украйниі Берестейщини, Підлящшя й Холмщини в першій половині ХХ сm. Хроніка подій, Київ 1997.

Дмитріюк В., Дорогами війни та миру, [b.m.w.] 2012.

Ильин А., Шалаш поэтов, „Гістарычная брама: гісторыя і культура Палесся” (2004), nr 1.

Ильин А., Всплеск русского движения в Давид-Городке в 1928-1931 годах, w: Берасиейскі хранограф: зб. навук. праи., ред. М. Часноўскі, вып. 4, Брэст 2004.

Кисілевська О., По рідному краю, Коломия 1935.

Мазько Э., Палессе у каниэпиыях беларускіх палітычных партый Заходняй Беларусі, w: Загароддзе-3, ред. Ф. Клімчук, А. Энгелькінг, В. Лабачэўская, Мінск 2001.

Мисиюк В., Исследование национальных процессов в Восточной Европе на примере Полесского воеводства (1921-1939 г2.), „Перекрёстки” (2007), nr 3-4.

Мисиюк В., Национальные процессы и церковь в Полесском воеводстве (1921-1939 г2.), „Перекрёстки” (2009), nr 1-2.

Місіюк В., Просвіта на Поліссі (1923-1938 рр.), „Наукові записки Національного університету «Острозька академія»: Історичні науки" (2013), nr 21.

Монтвилов М., Русская гимназия в Бресте на Буге 1919-1939 г2., Ним-Брест-Минск 1996.

Одрач Ф., Наше Полісся, „Пам'ятки України” (2002), nr 3-4.

Пашкевіч А., Нащыянальныя пращэсы ў Палескім ваяводстве у 1920-я г2. праз прызму вынікаў выбарчых кампаній у польскі парламент, „Arche” (2013), nr 4.

Терешкович П., Этническая история Беларуси ХIX - начала XX в. в контексте Центрально-Восточной Европь, Минск 2004.

Ціхарацкі П., „Паляшук” - аб’ект цыьвілізащьийнай місіі і пакрыуджаны суайчыннік. Праваслаўныя вясковыя жыхары Палескага ваяводства ў польскай папулярнай літаратуры міжваеннага перыяду, „Аrсhе” (2014), nr 7-8.

Швайко В., Русская диаспора в Польще в 20-30 г2. ХХв., „Диаспоры” (2004), nr 2.

Pavel Ablamski, doktorant w Instytucie Historii im. Tadeusza Manteuffla Polskiej Akademii Nauk. Zainteresowania badawcze: mniejszości narodowe i polityka narodowościowa państw Europy Środkowo-Wschodniej w okresie międzywojennym, historia polityczna i społeczna wschodnich województw II Rzeczypospolitej (ablamski@gmail.com).

Pavel Ablamski, PhD student at The Tadeusz Manteuffel Institute of History of the Polish Academy of Sciences. Research interests: national minorities and nationality policy of the interwar East-Central Europe, political and social history of the Eastern voivodeships of the Second Polish Republic (ablamski@gmail.com). 